\title{
Reversal of hair greying following autologous adipose mesenchymal stem cell transplantations: a coincidental finding
}

Jaymesh Thadani ${ }^{1}$, Prashant Kshatriya ${ }^{1}$, Anant Marathe ${ }^{1}$, Rajni Vyas' ${ }^{1}$, Bhaskar Vyas ${ }^{1 *}$ and Kaushik Deb²

*Correspondence: bhaskarvyas2007@gmail.com

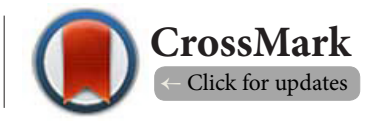

${ }^{1}$ Total Potential Cells (P) LTD, Parimal, Pratap Road, Raopura, Vadodara- 390 001, India.

${ }^{2}$ Merisis Therapeutics, DiponEd Biolntelligence, Bomasandra Industrial Area, Bangalore 560099, KA, India.

\begin{abstract}
Adipose derived autologous mesenchymal stem cells have been transplanted and tested for their ability to regenerate tissues for several indications. While treating various age related neurodegenerative disorders with autologous mesenchymal stem cells for their regenerative and rejuvenating properties, we accidentally observed a transition of hair colorations from mostly grey to black in all the 4 elderly patients. We have given 20million cells intravenous and also 20 million cells intrathecal, in multiple sessions to each patient. Though low dose the effects were very obvious and may indicate an anti aging effect. We also found that the effect was transient and changed with time through a follow up period of 20 months. This may be through positive activation and regeneration of melanocyte stem cells in the hair follicular niche. In this paper we intend to report this unique observation which may lead to further research and solutions to problems like premature greying of hair or indicate new anti aging solutions.
\end{abstract}

Keywords: Mesenchymal stem cells, human hair, melanocyte, melanin

\section{Introduction}

Many neurodegenerative changes and diseases are caused by ageing. Mesenchymal stem cells (MSCs) are likely to emerge as a promising therapy for neurological regeneration [1-5]. Such cellular therapies have recently demonstrated an advantage as they do not elicit any immune reaction $[6,7]$. We have been conducting a clinical trial with autologous MSCs for such age related neurodegenerative disorders. There are no treatment options available currently for such neurodegenerative conditions.

The trial was conducted as per Guidelines given by Indian Council of Medical Research (ICMR). Approvals for clinical trials were obtained from Institutional Ethics Committee (IEC) and Institutional Stem Cell Research Committee (ISCRC).

\section{Materials and methods}

The patient's preparation for the implantation of cells was done after detailed clinical and laboratory investigations that include liver, kidney functions and hematological investigations etc.

The autologous MSCs were harvested from $200 \mathrm{ml}$ of lipoaspirate by liposuction from lower abdomen subcutane- ous tissue under local anesthesia. Stem cells from the adipose tissue were isolated following a fastidious protocol in our GMP Class V laboratory. The yield was about more than 100 million cells on an average. About 5 million cells were put for culture and passaging for 2 passages. This protocol yielded about 40 million Mesenchymal stem cells. MSC cell markers used for identification in our lab were CD29, CD90, CD 44, CD 105 positive markers \& negative markers are CD 45, CD 31, CD 34 and HLA-DR (Figures 1 and 2).

Each patient received more than one session within a time frame of 2-3 weeks. Each time the MSCs were administered by spinal intrathecal route ( 20 million) and intravenously ( 20 million) after over a period of 20 minutes.

\section{Results}

We treated a total number of 14 patients between the age group 38-75 years, out of them 4 subjects had completely grey hair. Three subjects were males and one female. There were no notable complications post transplantations. We observed remarkable improvement in the neurological status 


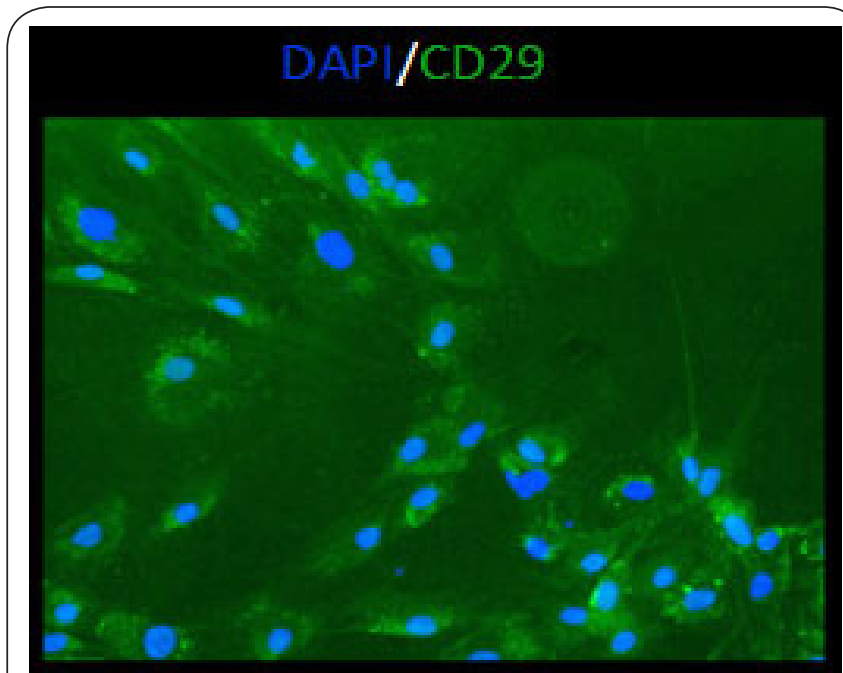

Figure 1. Characterization of the mesenchymal stem cells. Green indicates the positive expression CD 29 and blue indicates the nuclear staining by DAPI.

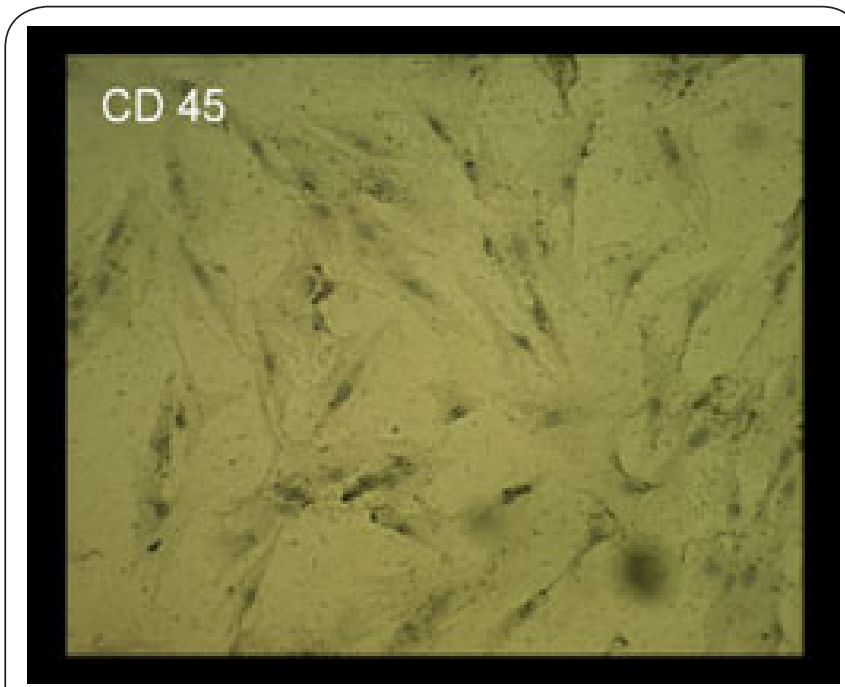

Figure 2. Characterization of the mesenchymal stem cells. CD 45 expression is negative in the cells.

(being reported separately) and the only adverse effect was transient headache.

In observed patients about $50 \%$ of the hairs were seen turning black after duration of 3-6 weeks (Figures 3 and 4). This was observed on the scalp and on the beard as well. However, the effect was not permanent; as the age progressed the greying process continued. The longest period of follow up was 20 months for all the 4 patients. All the subjects continue to have some black hairs but were now lesser in density and number.

\section{An illustrative case report}

Mr. C, aged 70 years, was diagnosed for progressive supra

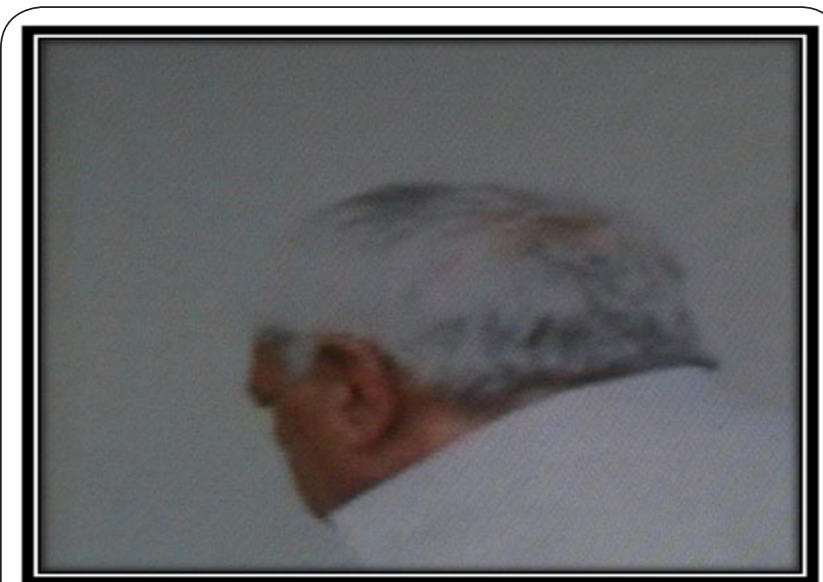

Figure 3. Photograph indicates more than $90 \%$ white hairs in subject ( $\mathrm{Mr}$ a) before treatment.

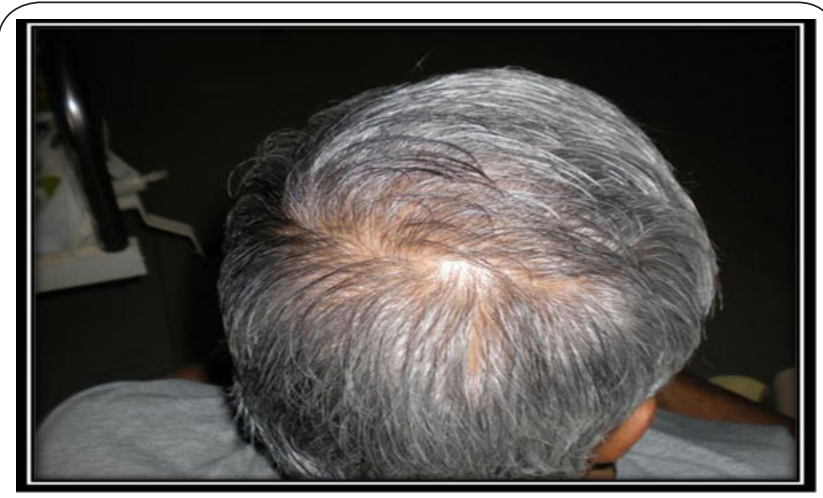

Figure 4. Photograph indicated the growth of Black hairs in the same subject ( $\mathrm{Mr}$ a) post treatment.

nuclear palsy. He had fixed gaze, unstable gait, frequent falls, slurred speech, difficulty in swallowing, uncoordinated limb movement was increased, frequency of urination with loss of bladder control etc. This patient was treated with adipose derived mesenchymal stem cells (ADMSCs) as the first session. A second session with cultured ADMSCs following two passages was done after 3 weeks. More mesenchymal stem cells were similarly transplanted on the $3^{\text {rd }} \& 4^{\text {th }}$ sessions. During first three weeks of his treatment, we observed improvement in his neurological status. Besides this, an interesting finding was observed that many of his grey hair turned black during this course (Figures 5 and $\mathbf{6}$ ). Similar results were obtained with the three other patients Table 1.

\section{Discussion}

We do not view MSCs as a treatment modality for grey hair. However this is an incidental finding, so far not reported in the literature. We noted it accidentally during the course of treatment for various neurodegenerative disorders. The homing properties of stem cells are known to promote and propel the 


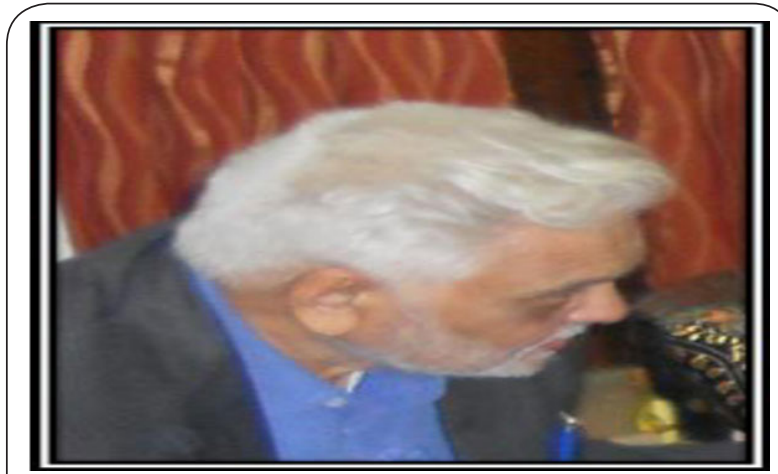

Figure 5. Photograph indicates more than $90 \%$ white hairs in subject $(\mathrm{Mrc})$ before treatment.

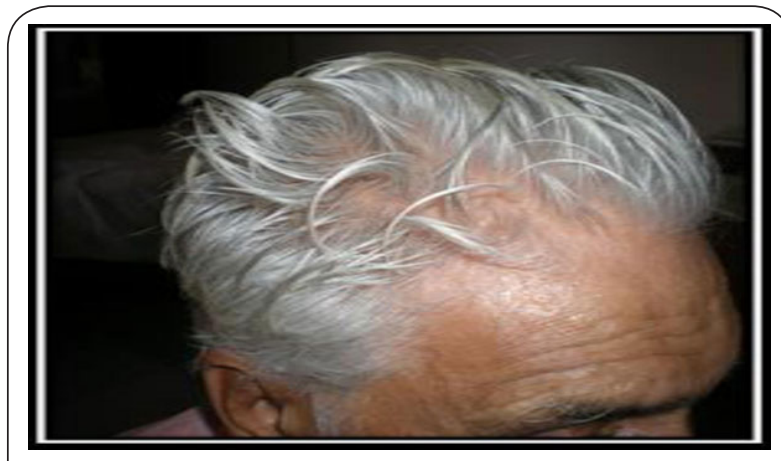

Figure 6. Photograph indicated the growth of Black hairs in the same subject $(\mathrm{Mr} \mathrm{c}$ ) post treatment.

MSCs to target the neuro-degenerative tissues [8]. The elaborate mechanisms that correlate with the functions of MSCs are briefly summarized as follows: MSCs have 1) multilineage
Table 1. MSCs therapy protocol and description of the patients with various neurological diseases.

\begin{tabular}{llllll}
\hline $\begin{array}{l}\text { Name of } \\
\text { Patient }\end{array}$ & Gender & Disease & Age & $\begin{array}{l}\text { Number of } \\
\text { sessions }\end{array}$ & $\begin{array}{l}\text { Route of } \\
\text { injection }\end{array}$ \\
\hline A & F & $\begin{array}{l}\text { Cerebral } \\
\text { palsy }\end{array}$ & 38 & 4 & $\begin{array}{l}\text { I.V. (2) \& } \\
\text { Spinal (2) }\end{array}$ \\
\hline B & M & $\begin{array}{l}\text { Acute spine } \\
\text { injury }\end{array}$ & 67 & 2 & $\begin{array}{l}\text { I.V. (1) \& } \\
\text { Spinal (1) }\end{array}$ \\
\hline C & M & $\begin{array}{l}\text { Progressive } \\
\text { Supranuclear } \\
\text { palsy }\end{array}$ & 70 & 4 & $\begin{array}{l}\text { I.V. (2) \& } \\
\text { Spinal (2) }\end{array}$ \\
\hline D & M & $\begin{array}{l}\text { Progressive } \\
\text { autoimmune } \\
\text { disease of } \\
\text { anterior horn } \\
\text { of motor } \\
\text { nerves }\end{array}$ & & & \\
& & & & I.V. (1) \& \\
& & & & \\
& & & & \\
& & & & \\
\hline
\end{tabular}

translational capacity, 2) facility to migrate to affected tissue and translate to it, 3) anti inflammatory property by virtue of paracrine secretions, 4) regenerative capability; 5) they are capable of vasculogenesis and angiogenesis (Figure 7).

The production of melanin in the hair follicles of the scalp are known to be regulated by several molecules like alpha melanocyte stimulating hormone, adrenocorticotrophic hormone, basic fibroblast growth factor, nerve growth factor, hepatocyte growth factor [9]. OA1, P, MATP, ATP7A, BLOC-1 [10-12] to synthesize eumelanin and pheomelanin $[13,14]$. Microtubules in the hair are involved in transport of melanin from follicular bulb to hair [15-17]. So far, to our knowledge, hardly any information is available on the underpinning causes of grey hair. It is obvious that melanin pigment is

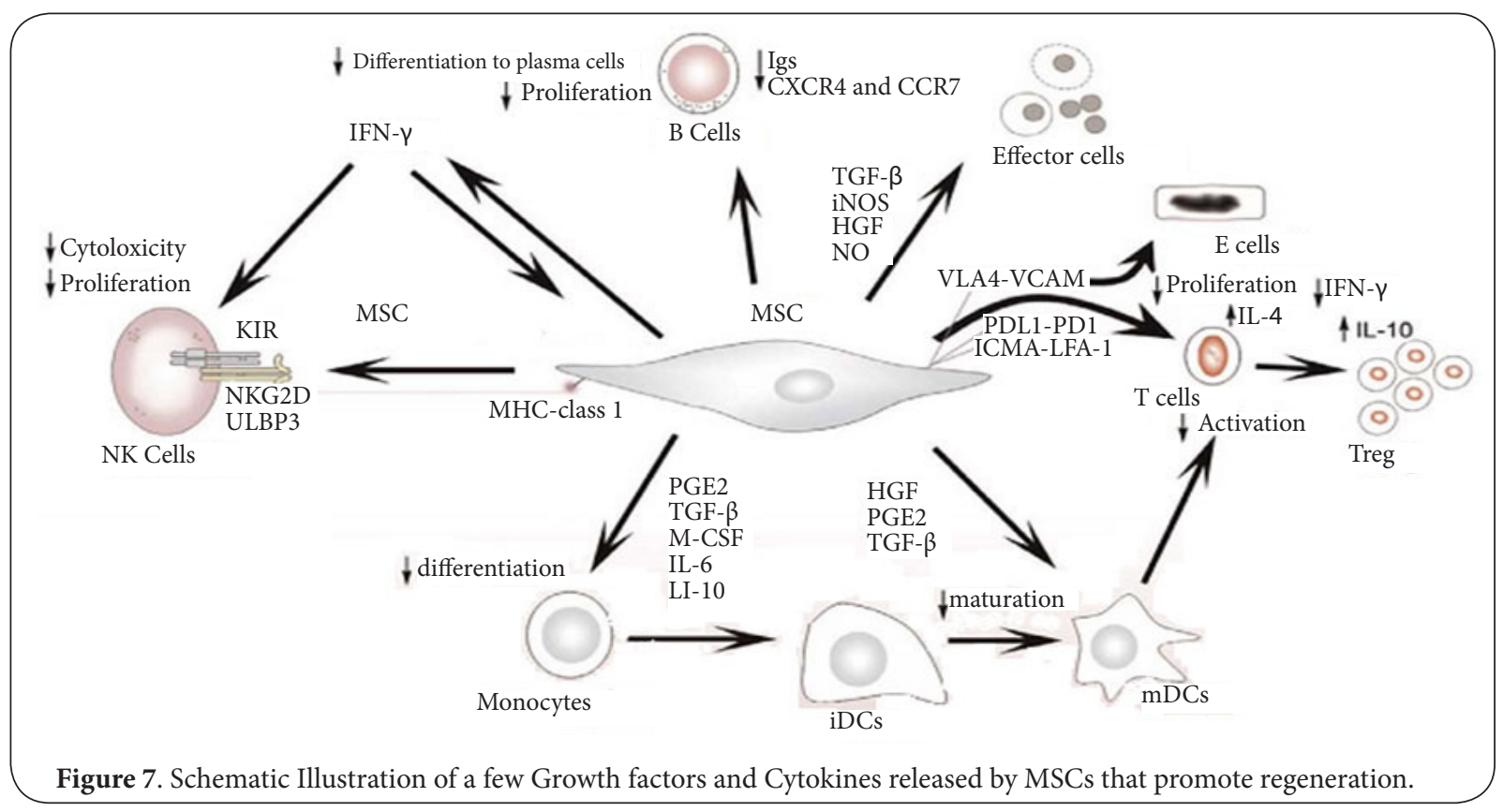


Thadani et al. Stem Cell Biology and Research 2015,

http://www.hoajonline.com/journals/pdf/2054-717X-2-3.pdf

doi: 10.7243/2054-717X-2-3

responsible for the coloration of skin and hair. It is produced by the melanocytes. Melanoblasts are the precursors to melanocytes that originate in the neural crest and travel to hair follicular bulb and differentiate in to melanocytes $[18,19]$. A recent study has shown that loss of color is due to dysfunction of melanocyte stem cells in hair follicular bulb [20]. It can be derived that MSCs travel to the diseased, dysfunctional brain area and affect the neural crest through their cytokines. This in turn will up-regulate the melanin cycle. MSCs might be positively influencing all of these factors and help in up-regulating the pathways involved in proliferation and differentiation of hair follicular bulb. This indicates a possible treatment for people with premature greying of hairs and anti aging solutions in case there are more reports with similar findings.

With this observation one can postulate that MSCs find their way to the hair follicles in the scalp and beard to up regulate the production of melanin by activating all the above factors. Stem Cell tracking experiments will be required to establish the possible role of MSCs in up-regulation of malanocyte stimulation pathways.

\section{Conclusion}

This is a report of 4 cases of neurodegenerative disorders. While treating them with MSCs, it was incidentally observed that their grey hair started turning black. This generates an interesting hypothesis, that MSCs play an important role in melanin regulating pathways, biosynthesis and transport into hair follicular bulb. The cellular and molecular pathways remains a subject of future research.

\section{Competing interests}

The authors declare that they have no competing interests.

Authors' contributions

\begin{tabular}{|l|c|c|c|c|c|c|}
\hline Authors' contributions & JT & PK & AM & RV & BV & KD \\
\hline Research concept and design & -- & -- & $\checkmark$ & $\checkmark$ & -- & $\checkmark$ \\
\hline Collection and/or assembly of data & $\checkmark$ & $\checkmark$ & $\checkmark$ & $\checkmark$ & $\checkmark$ & -- \\
\hline Data analysis and interpretation & -- & -- & -- & $\checkmark$ & $\checkmark$ & $\checkmark$ \\
\hline Writing the article & -- & -- & -- & $\checkmark$ & $\checkmark$ & -- \\
\hline Critical revision of the article & -- & -- & -- & $\checkmark$ & -- & $\checkmark$ \\
\hline Final approval of article & -- & -- & -- & -- & $\checkmark$ & -- \\
\hline Statistical analysis & $\checkmark$ & $\checkmark$ & -- & -- & -- & -- \\
\hline
\end{tabular}

\section{Acknowledgement}

We are thankful to Prof. Bharat Chattoo for rendering help of Confocal Microscope in M.S. University, Baroda, India.

Publication history

Editor: Kiminobu Sugaya, University of Central Florida, USA. EIC: Prasad S. Koka, Haffkine Institute for Training, Research \& Testing, India.

Received: 18-Sep-2015 Final Revised: 29-Oct-2015

Accepted: 10-Nov-2015 Published: 19-Nov-2015

\section{References}

1. Chen J and Chopp M. Neurorestorative treatment of stroke: cell and pharmacological approaches. NeuroRx. 2006; 3:466-73. | Article |

\section{PubMed Absract | PubMed Full Text}

2. Xiong $Y$, Mahmood $A$ and Chopp M. Angiogenesis, neurogenesis and brain recovery of function following injury. Curr Opin Investig Drugs. 2010; 11:298-308. | PubMed Absract | PubMed Full Text

3. Rosaria Giordano, Margherita Canesi, Maurizio Isalberti, Ioannis Ugo Isaias, Tiziana Montemurro, Mariele Vigan1, Elisa Montelatici, Valentina Boldrin, Riccardo Benti, Agostino Cortelezzi, Nicola Fracchiolla, Lorenza Lazzari and Gianni Pezzoli. Journal of Translational Medicine. 2014; 12:14.

4. Chen G, Wang Y, Xu Z, Fang F, Xu R, Hu X, Fan L and Liu H. Neural stem cell-like cells derived from autologous bone mesenchymal stem cells for the treatment of patients with cerebral palsy. J Trans/ Med. 2013; 11:21. | Article | PubMed Absract | PubMed Full Text

5. Satake K, Lou J and Lenke LG. Migration of mesenchymal stem cells through cerebrospinal fluid into injured spinal cord tissue. Spine (Phila Pa 1976). 2004; 29:1971-9. | Article I PubMed

6. Weissman IL. Stem cells: units of development, units of regeneration, and units in evolution. Cell. 2000; 100:157-68. | Article | PubMed

7. Barry FP and Murphy JM. Mesenchymal stem cells: clinical applications and biological characterization. Int J Biochem Cell Biol. 2004; 36:568-84. | Article | PubMed

8. Zuk PA, Zhu M, Ashjian P, De Ugarte DA, Huang JI, Mizuno H, Alfonso ZC, Fraser JK, Benhaim $P$ and Hedrick MH. Human adipose tissue is a source of multipotent stem cells. Mol Biol Cell. 2002; 13:4279-95. | Article | PubMed Absract | PubMed Full Text

9. Bussolino F, Di Renzo MF, Ziche M, Bocchietto E, Olivero M, Naldini L, Gaudino G, Tamagnone L, Coffer A and Comoglio PM. Hepatocyte growth factor is a potent angiogenic factor which stimulates endothelial cell motility and growth. J Cell Biol. 1992; 119:629-41. | Article | PubMed Absract | PubMed Full Text

10. Imokawa G, Kobayashi T, Miyagishi M, Higashi K and Yada Y. The role of endothelin-1 in epidermal hyperpigmentation and signaling mechanisms of mitogenesis and melanogenesis. Pigment Cell Res. 1997; 10:218-28. | Article | PubMed

11. Nishimura E.K, Jordan S.A, Oshima H, Yoshida H, Osawa M.M, Jackson I.J, Barrandon $\mathrm{Y}$, Miyachi $\mathrm{Y}$ and Nishikawa S. Dominant role of the niche in melanocyte stem-cell fate determination. Nature. 2002; 416:854-860. | Article

12. Yoshida H, Kunisada T, Kusakabe M, Nishikawa S and Nishikawa SI. Distinct stages of melanocyte differentiation revealed by anlaysis of nonuniform pigmentation patterns. Development. 1996; 122:1207-14. | Article I PubMed

13. Chakraborty AK, Funasaka Y, Slominski A, Ermak G, Hwang J, Pawelek $J M$ and Ichihashi $M$. Production and release of proopiomelanocortin (POMC) derived peptides by human melanocytes and keratinocytes in culture: regulation by ultraviolet B. Biochim Biophys Acta. 1996; 1313:130-8. | Article | PubMed

14. Takeuchi T. Genetic analysis of a factor regulating melanogenesisin the mouse melanocyte. Jpn. J. Genet. 1968; 43:249-256.

15. Wilkie AL, Jordan SA and Jackson IJ. Neural crest progenitors of the melanocyte lineage: coat colour patterns revisited. Development. 2002; 129:3349-57. | Article | PubMed

16. Fang D, Kute T and Setaluri V. Regulation of tyrosinase-related protein-2 (TYRP2) in human melanocytes: relationship to growth and morphology. Pigment Cell Res. 2001; 14:132-9. | Article | PubMed

17. Jordan SA and Jackson IJ. MGF (KIT ligand) is a chemokinetic factor for melanoblast migration into hair follicles. Dev Biol. 2000; 225:424-36. | Article | PubMed

18. Takeuchi T. Genetic analysis of a factor regulating melanogenesis in the mouse melanocyte. Jpn. J. Genet. 1968; 43:249-256. | Article

19. Chakraborty AK, Funasaka Y, Slominski A, Ermak G, Hwang J, Pawelek $\mathrm{JM}$ and Ichihashi M. Production and release of proopiomelanocortin 
Thadani et al. Stem Cell Biology and Research 2015,

http://www.hoajonline.com/journals/pdf/2054-717X-2-3.pdf

(POMC) derived peptides by human melanocytes and keratinocytes in culture: regulation by ultraviolet B. Biochim Biophys Acta. 1996;

1313:130-8. | Article | PubMed

20. Zuk PA, Zhu M, Ashjian P, De Ugarte DA, Huang JI, Mizuno H, Alfonso ZC, Fraser JK, Benhaim $\mathrm{P}$ and Hedrick MH. Human adipose tissue is a source of multipotent stem cells. Mol Biol Cell. 2002; 13:4279-95. | Article | PubMed Absract | PubMed Full Text

\section{Citation:}

Thadani J, Kshatriya P, Marathe A, Vyas R, Vyas B and Deb K. Reversal of hair greying following autologous adipose mesenchymal stem cell transplantations: a coincidental finding. Stem Cell Biol Res. 2015; 2:3. http://dx.doi.org/10.7243/2054-717X-2-3 